\title{
Teacher's Attitude and Peer Acceptance to Children with Special Needs in Inclusive Primary Schools
}

\author{
Marlina \\ Department of Special Education, Faculty of Education, \\ Universitas Negeri Padang \\ Padang, Indonesia \\ Correspondinge-mail: marlina.muluk@gmail.com
}

\begin{abstract}
The success of inclusion of children with special needs in inclusive schools largely depends on teachers' attitudes towards students with special needs and their knowledge on how to properly educate them. Regular teachers have different views about the inclusion of students with special needs. The type and level of the children's disabilities affect teachers' willingness to accommodate students with special needs and effective classroom management. The research used descriptive survey method to know the attitude and level of peer acceptance to children with special needs in Padang inclusive schools, West Sumatera, Indonesia in year 2015. The subjects of research consist of 150 regular school teachers and special education teachers who worked full-time in inclusive schools and 85 children with special needs that had been identified with the Kit of Identification Children with Special Needs. The data were collected with teacher attitudes and sociometric nomination scales. The results show that teacher attitudes on integration are not related to teaching experience, teacher educational background is positively related to their attitudes, and teachers' teaching experiences are related to attitudes. Other findings indicate that the level of peer acceptance in children with special needs is largely in the category of being ignored and even rejected by their peers.
\end{abstract}

Keywords: $\quad$ teacher's attitude, peers acceptance, children with special needs

\section{INTRODUCTION}

The educational policy for children with special needs has now moved from the segregation system (the system that completely separates children with special needs from other ordinary children) to the system that still considers certain conditions of children with special needs to be educated in regular schools (mainstreaming system) and to the system that fully combines children with special needs with ordinary children in one school (inclusive). In recent decade, the view of special education has changed in all societies. The ideology of inclusive education is the school that accommodates the learning needs of all learners without exception. Schools that match the needs of all students. Schools that are responsible for providing educational and learning services according to the special needs of learners. This is explicitly stated in the Regulation of National Education Minister on Republic of Indonesia Number 70 Year 2009 about inclusive education for students with special needs.

International agreements on human rights also prohibit the exclusion or limitation toward educational opportunities in terms of gender, ethnic origin, language, religion, ethnicity, social background, economic conditions, abilities, and so on. Schools do not only provide the opportunities for children with special needs, but these schools also proactively identify the challenges and barriers in accessing appropriate education (UNESCO, 2013). With the proclamation of West Sumatra Province as the inclusive province, it provides the impacts on the access of children with special needs to be served in regular schools. But in recent years, it has shown that the teachers' attitudes toward children with special needs become an extensive research focus (Dapudong, 2013). The effectiveness of inclusion can be influenced by the attitudes of teachers who are directly involved. Lopes, e.al. (2004) stated that most teachers do not fully accept inclusion because they do not know how to implement the learning and support for children with special needs.

Inclusive education can be defined as the philosophy and practice of education on children with special needs in general educational setting (Bryant, Smith, \& Bryant, 2008; Salend, 2001). Children with special needs gain benefit from regular classroom learning, while their peers also benefit from children with various characteristics, talents and temperaments. In other words, children with special needs can achieve better academic results in regular education because they can learn from other children that are more capable (Ruijs, Peetsma, \& Van der Veen, 2010). This opinion is reinforced by the results of research showing that children with special needs in inclusive schools scores higher than those in special schools (Boer, at.al, 2011). In addition to academic benefits, it is also socially beneficial for children with special needs, such as peers acceptance and possible friendships (Lindsay, 2007, Marlina, 
2015). It is clear that children with special needs' social participation in public education is an important issue in the development of inclusive education.

Prior to this period, the attitudes of societies, governments and, citizens toward children with special needs were very negative, they were considered incapable of contributing anything meaningful to society. One of the important aspects from the individual that is mentioned by the teachers is "attitude". Their attitudes to themselves, their works, their students and many other things depend on the number of variables that will affect their productivities. The assessment is expressed by the teachers who may react to the new policy on inclusive education in their schools, reflecting the general attitudes of modern educators on the paradigm shift in educational policy. Those attitudes are categorized in two, namely the attitudes toward the ability of children with special needs in their classes and the attitudes about the effort that he wants for the children with special needs. Both of these attitudes have an important effect on the teaching style and classroom management that incorporate the children with special needs into the inclusive class.

In the study conducted by Bond \& Castagnera (2008) about the teacher attitudes towards inclusion for children with hearing disorder in regular schools, it was revealed that the teachers' attitudes indicated the doubt to accept them. Ogbue (1995) also conducted an interview on Lagos State about inclusion for children with special needs in regular schools. The findings were from 200 regular primary school teachers that have been interviewed, $60 \%$ of them refused to be inclusive, while $35 \%$ of them wanted the inclusion because they were adequately trained. The remaining 5\% are in doubt. Therefore, lots of these negative attitudes will have a bad effect on children with special needs' education in Nigeria. Elliot (2008) examines the relationship between teachers' attitudes towards inclusion in children with mental disorder and the efforts that haven been done, the level of success achieved by the children with mental disorder as well as comparing it with their peers that do not have disabilities. The results showed that teachers who had positive attitudes towards inclusion significantly had an effect on higher achievement on children with special needs.

Another factor that also affects the success of children with special needs in inclusive schools is the peers acceptance. Through their peers, children with special needs try to be socially acceptable (Hetherington \& Parke, 1999). Peers acceptance is the acceptance of a person as a friend for an activity in the group that he or she become the member and becomes the index of the child's success in playing a role in the group and demonstrating the degree of interest from the group members to work or play with that child (Buhs \& Ladd, 2001). Experience with peers can stimulate cognitive development, social skills, and social cognition, it can ease the students on the transition from the family into the wider environment, also providing the contribution to the perception and performance of the school (Ladd, 1990; Diehl, et al., 1998).

Children who are received by their peers indicate high learning results, while rejected children are at risk of academic failure. Children who are accepted by their peers show the characteristics of becoming themselves, happy, enthusiastic, confident but not arrogant, communicating clearly and maintaining conversation (Bakker \& Bosman, 2003). Ladd \& Buhs (1999) added that they are friendly, cooperative, adjusting themselves without causing problem, accepting happily of the situation that happens, having good relationships with others, sharing, taking turns in group games, being responsible, participating and enjoying social relationship, making comparisons between self and peer, emotionally mature, controlled behavior, calm, and free from anxiety, anger or jealousy. While children who are rejected by their peers tend to show negative attitudes toward school, avoiding school, and underachiever on comfort level, interaction, intuition and children's cognitive is troubled, and lower school performance compared with their peers that are average and popular children.

The above description shows that teachers' attitudes and peer acceptance are crucial on the success of children in inclusive schools. Based on those descriptions, then the problems to be answered in this article are as follow: (1) Is there significant difference in teachers' attitudes towards inclusion for children with special needs in inclusive schools between male and female teachers? (2) Is there significant difference in teachers' attitudes towards inclusion for children with special needs in inclusive schools between the teachers that attend training on special education and teachers who have not received training on special education? (3) Is there significant difference in teachers' attitudes towards inclusion for children with special needs in inclusive schools between government teachers and honorary teachers? (4) Is there significant difference in teachers' attitudes towards inclusion for children with special needs in inclusive schools between teachers with 1-9 years teaching experience and teachers with more than 10 years' teaching experience? (5) How is the level of peer acceptance at children with special needs at inclusion school?

\section{METHOD}

\subsection{Research Sample}

This research uses descriptive approach. The sample consists of 150 teachers that teach in inclusive primary schools at Padang City, West Sumatera. The sample data were grouped into four 
aspects, namely gender, marital status, professionalism, and teaching experience.

Table 1. Research Sample Data (Teachers)

\begin{tabular}{|c|c|c|c|}
\hline No & Variable & $\mathbf{N}$ & Percentage \\
\hline \multirow[t]{3}{*}{1} & Gender & & \\
\hline & Male & 40 & $26,7 \%$ \\
\hline & Female & 110 & $73,3 \%$ \\
\hline \multirow[t]{4}{*}{2} & Training on Special & & \\
\hline & Education & 136 & $90,6 \%$ \\
\hline & Yes & 14 & $9,4 \%$ \\
\hline & No & & \\
\hline \multirow[t]{4}{*}{3} & Work Status & & \\
\hline & Government & 122 & $81,3 \%$ \\
\hline & Teacher & 28 & $18,7 \%$ \\
\hline & Honorary Teacher & & \\
\hline \multirow[t]{3}{*}{4} & Teaching Experience & & \\
\hline & $1-9$ years & 80 & $53,3 \%$ \\
\hline & Over 10 years & 70 & $46,7 \%$ \\
\hline \multirow[t]{5}{*}{5} & Teaching Experience on & & \\
\hline & Children with Special & & \\
\hline & Needs & 130 & $86,67 \%$ \\
\hline & Yes & 20 & $13,33 \%$ \\
\hline & No & & \\
\hline
\end{tabular}

While the sample of children with special needs is determined by: (1) listing the inclusive school in Padang City, (2) identifying the children with special needs by using the Kit of Identification Children with Special Needs (KICSN), and (3) purposively the children with special needs that are involved in this research are class V Primary School. The consideration is that grade $\mathrm{V}$ primary school students can already fill sociometric nominations and perceive relationships with their peers. Based on KICSN, there are 85 children with special needs (50 male and 35 female).

Table 2. Research Sample Data (Children with Special Needs)

\begin{tabular}{lcc}
\hline \multicolumn{1}{c}{ Types of Special Needs } & N & Percentage \\
\hline $\begin{array}{l}\text { General learning difficulty } \\
\text { Language understanding }\end{array}$ & 19 & $22,33 \%$ \\
$\begin{array}{l}\text { disorders } \\
\text { Language expression }\end{array}$ & 12 & $14,10 \%$ \\
$\begin{array}{l}\text { disorder } \\
\text { Dyslexia }\end{array}$ & 10 & $11,74 \%$ \\
Dysgraphia & 8 & $9,39 \%$ \\
$\begin{array}{l}\text { Dyscalculia } \\
\text { Orientation disturbance }\end{array}$ & 7 & $8,48 \%$ \\
Physically handicapped & 6 & $7,03 \%$ \\
$\begin{array}{l}\text { Attention deficit disorder } \\
\text { Emotional and behavioral }\end{array}$ & 5 & $7,03 \%$ \\
disorders & 5 & $5,86 \%$ \\
Communication disorders & 3 & $5,86 \%$ \\
$\quad$ Total & 85 & $3,50 \%$ \\
\hline
\end{tabular}

\subsection{Measurement}

The teachers' attitude data is measured by using the teachers' attitude scale referring to the concept of
Coie (in Buhs \& Ladd, 2001), to measure the teachers' attitudes toward inclusion on children with special needs in inclusive schools. The scale consists of 20 items consisting of four Likert scales in the form of self-report of "positive attitude" to "negative attitude" (1-4). Researchers manage the instruments in each selected school after obtaining the permission from each principal. In each school, the respondents were collected in a class and completed the questionnaire. The direction of questionnaires were read to the respondents in accordance with the contents of questionnaire. Once filled by the respondent, the questionnaire was submitted immediately with the return rate of $93 \%$.

Peer acceptance level data is measured by sociometric nominations consisting of positive nominations (Who is your favorite classmate?) and negative nominations (Who is your classmate that you don't like?) (Wentzel, 1991). This nomination is given to all children with special needs in the class, all the children in one class fill positive and negative nominees of their 3 friends. Each nomination is accompanied by the reason for choosing those friends as the most liked and least favored. Data analysis uses Wentzel index (1991) with the following criteria:

1. Popular, the child is popular if the score $\mathrm{SP}>1.0$, $\mathrm{LM}>0$ and $\mathrm{LL}<0$.

2. Controversial, the child is controversial if the score $\mathrm{SI}>1.0, \mathrm{LM}>0$, and $\mathrm{LL}>0$.

3. Average, a child is average if the SP score is $>$ 0.5 , and $\mathrm{SI}<0.5$.

4. Neglected, a child is neglected if the SI score is $<-1.0, \mathrm{LM}<0$, and $\mathrm{LL}<0$.

5. Rejected, a child is rejected if SP score $<-1.0$, $\mathrm{LM}<0$, and $\mathrm{LL}>0$.

Information:

$\mathrm{SP}=$ Social Preference $(\mathrm{SP}=\mathrm{LM}-\mathrm{LL})$.

SI $=$ Social Impact $(\mathrm{SI}=\mathrm{LM}+\mathrm{LL})$.

LM $=$ Liked Most

$\mathrm{LL}=$ Liked Least

\subsection{Predictor Variables}

Teachers are asked to complete biographical questionnaire containing about gender, marital status, employment status, and teaching experience, all things that relate to teachers' attitudes on inclusion to children with special needs in inclusive schools.

\section{RESEARCH RESULT}

\subsection{Results of Teacher Attitudes Analysis on Inclusion for Children with Special Needs}

The results of research to answer hypothesis 1 of "there is no significant difference in teachers' attitudes towards inclusion for children with special 
needs in inclusive schools between male and female teachers" is presented in the following table.

Table 3 shows that the male teachers' attitude are 2.87 while the female teachers are 3.37 , the t-test analysis shows that the t-count test is -6.78 , with the probability of 0.000 . Because the probability $>-6.78$, then $\mathrm{H}_{0}$ is accepted. In other words, there is no significant difference between male and female teachers. Since the average score of female teachers is higher than the male teachers, then the female teachers have more positive attitude towards the inclusion of children with special needs rather than the male teachers.

The result of research in answering hypothesis 2 of "there is no significant difference of teacher attitudes towards inclusion for children with special needs in inclusive school between teacher who had been participated in training of special education and teacher who had not been participated in training of special education" is presented in the following table.

Table 4 shows that teachers who have attended special educational training are 2.85 whereas teachers who have not attended special education training are 3.04 , t-test analysis shows that t-count test is -2.27 , with the probability of 0.024 . Since the probability is $>-2.27$, then $\mathrm{H}_{0}$ is accepted. In other words, there is no significant difference between teachers have attended special educational training and teachers who have not attended special educational training. Because the average scores of teachers who have attended special educational training are lower than those who have not attended special educational training, then the teachers who have not attended special education training have negative attitude towards the inclusion of children with special needs to the inclusive school.

The result of research in answering hypothesis 3 of "there is no significant difference of teacher attitude toward inclusion for children with special needs in inclusive school between government teachers and honorary teachers" is presented in following table.

Table 5 shows that government teachers are 2.88 while the honorary teachers are 2.65, the t-test analysis shows that the t-count test is 3.14 , with the probability of 0.002 . Since the probability $<3.14$, then $\mathrm{H}_{0}$ is rejected. In other words, there is significant difference between government teachers and honorary teachers. Because the average score of honorary teachers are lower than government teachers, the honorary teachers have negative attitude towards the inclusion of children with special needs to the inclusive school.

The result of research in answering hypothesis 4 of "there is no significant difference in teacher attitudes towards inclusion for children with special needs in inclusive schools between teachers who have 1-9 years teaching experience and teachers with more than 10 years teaching experience" is presented in the following table.
Table 6 shows that teachers with 1-9 years teaching experience are 2.61 whereas teachers with teaching experience $>9$ years are 2.09. The t-test analysis shows that $\mathrm{t}$-count test is 6.12 , with the probability of 0.000 . Since the probability $<6.12$, then $\mathrm{H}_{0}$ is rejected. In other words, there is significant difference between teachers with 1-9 years teaching experience and teachers with more than 9 years teaching experience. Since the average score of teachers' with 1-9 years teaching experience is higher than the teachers with more than 9 years teaching experience, then the teachers with 1-9 years of teaching experience have negative attitude towards the inclusion of children with special needs to the inclusive school.

The result of research in answering hypothesis 5 of "there is no significant difference of teacher attitudes towards inclusion for children with special needs in inclusive school between teachers who have experience in teaching children with special needs and teachers who do not have experience in teaching children with special needs " is presented in the following table.

Table 7 shows that the teachers who have experience in teaching children with special needs are 2.76 while the teachers who do not have experience in teaching children with special needs are 2.43. The t-test analysis shows that the t-count test is 4.20 , with the probability of 0.000 . Since the probability $<4.20$, then $\mathrm{H}_{0}$ is rejected. In other words, there is significant difference between teachers who have experience in teaching children with special needs and teachers who do not have experience in teaching children with special needs. Since the average score of teachers who have experience in teaching children with special needs is higher than the teachers who do not have experience in teaching children with special needs, then the teachers who do not have experience in teaching children with special needs have negative attitude towards the inclusion of children with special needs to the inclusive school.

\subsection{Analysis Results of Peers Acceptance Level on Children with Special Needs}

The sociometric nomination results of peer acceptance indicates that the most nomination on children with special needs is rejected, the complete result is presented in the following table. 
Table 3. Percentage of Peers Acceptance Nomination Categories

\begin{tabular}{|c|c|c|c|}
\hline No & $\begin{array}{c}\text { Acceptance } \\
\text { Categories }\end{array}$ & Frequency & $\begin{array}{c}\text { Percentage } \\
(\%)\end{array}$ \\
\hline 1 & Rejected & 43 & 50,59 \\
\hline 2 & Neglected & 19 & 22,35 \\
\hline 3 & Average & 13 & 15,29 \\
\hline 4 & Controversial & 8 & 9,42 \\
\hline 5 & Popular & 2 & 2,35 \\
\hline & Total & 85 & 100 \\
\hline
\end{tabular}

Table 7 shows the children with special needs that have been rejected by most of their peers are 43 children $(50.59 \%)$, children with special needs who are ignored by most of their peers and socially marginalized, have few friends and often neglected are 19 children $(22.35 \%)$, children with special needs that are preferred by some peers and are disliked by others peers (average) are 13 children (15.29\%), children with special needs that most of their peers tend to like them are 8 children $(9,42 \%)$, and children with special needs that are more preferred by their peers (popular) are 2 children $(2.35 \%)$. The category of peer acceptance based on the subject's gender is presented in the following table.

Table 4. Categories of Peer Acceptance Based on Gender

\begin{tabular}{clccc}
\hline Code & Category of & \multicolumn{2}{c}{ Gender } & Total \\
& Acceptance & Male & Female & \\
\hline 1 & Rejected & 28 & 15 & 43 \\
2 & Neglected & 11 & 8 & 19 \\
3 & Average & 8 & 5 & 13 \\
4 & Controversial & 4 & 4 & 8 \\
5 & Popular & - & 2 & 2 \\
\hline & Jumlah & 51 & 34 & 85 \\
\hline
\end{tabular}

Table 8 shows that male children with special needs are mostly on the acceptance category of rejected and neglected compared to the female children with special needs. The analysis results on the reasons that have been mentioned by children with special needs and regular children are because children with special needs are aggressive, naughty, rebellious, like to fight, like to talk dirty, like to cross off walls and tables, nosy, like to lie, lazy, stingy, like to cry, angry, fussy, like to cheat, like to talk in learning, unsocial, select friends, look for attention, like to mock, like to insult, selfish, ignorant, not acknowledge their own mistakes, and like to cheat peers homework. While the reasons why the child is more popular than his peers is because he likes to help, maintain lines of communication, be himself, happy, enthusiasm and attention to others, diligent, smart, friendly, kind, courteous, honest, faithful, fun in learning, funny, fair, loyal friend, gentle, not arrogant, lively, firm, friends with everyone, and neat.

\section{DISCUSSION}

The result analysis of this research reveals that female teachers have more positive attitude towards the inclusion of children with special needs to inclusive schools than male teachers. Furthermore, teachers who attend special education training have positive attitude than teachers who do not attend special education training, while honorer teachers have negative attitude towards the inclusion of children with special needs to inclusive schools. Similarly, teachers with 1-9 years of teaching experience have negative attitude towards the inclusion of children with special needs to inclusive schools. Finally, teachers who do not have experience in teaching children with special needs have negative attitude towards the inclusion of children with special needs to inclusive schools.

According to the findings in this study, the teachers' negative attitudes are mostly because the lack of knowledge (Bier, et al, 2015). Many studies show that classroom teachers feel that they do not have adequate skills when children with special needs are included in the regular classes (Monaham, Miller \& Cronic, 1997). The positive attitudes of female teachers to children with special needs may be because women naturally have good tolerance over men. They are more calm and receptive than men. The findings of previous researchers suggest that teachers tend to behave better if they have: (a) high teaching competence, (b) more mature preparation in education, and (c) more teaching experience on children with special needs. However, the difference of gender in this study contradicts with previous findings by researchers such as (Rizzo \& Vispoel, 1991).

The results of analysis proves that the level of peer acceptance on children with special needs is mostly on the nomination of rejected. This means that the level of acceptance of children with special needs is at the bottom position, mostly rejected by their peers. Santrock (2002) states that this nomination is an alarming position for the social development of children, since the peers largely rejects the children with special needs. The results of this study are relevant with Vaughn, et.al. (1992) that in general, the children with special needs receive lower social acceptance rating than the normal children, and very few of them receive popular ratings. Why are children with special needs less preferred by their peers? First, because the lack of language skills and some other academic skills, it is difficult for them to interpret the situation and social interaction appropriately. Second, because the learning climate that involves teachers, other children, and the less conducive children with special needs, such as the improper teachers' treatments 
becomes the trigger for other children to dislike children with special needs.

Children with special needs are less liked by their peers because they often behave aggressively, this social behavior is less acceptable in the school environment. This study is relevant to Parker \& Asher (1993) that most children who are less accepted by their peers show the characteristics of naughty, cheating, and talking too much in the learning process. Parker \& Asher add that children who are not liked by their peers are at risk in selfadjustment and it becomes the predictor toward various problems for teenagers along with more serious problems in the form of antisocial behavior.

The rejected and neglected nominations that are received by children with special needs in this research have the effect on the next form of social acceptance, because those nominations are the vulnerable position in peer relationships. It means that the children will feel the wider social environment (like society) also neglect and even reject them. This condition will psychologically affect the children's perceptions about social circumstances. The nominations of rejected and neglected also affect toward learning outcomes, Wentzel (1998) states that children who are in the lowest position must struggle to be accepted by their peers, if the children feels accepted by their peers, it will cause the excitement in learning so that they can obtain satisfactory learning outcomes.

In addition, the rejected children tend to be dropout from school, this is because the children feel alone and have no friends, they are ignored and feel unacceptable by the environment, it will cause serious problem later compared with the neglected child. While the key factor in predicting the child that is rejected to be engaged in deviant behavior or school drop out later during their youth is the aggressiveness to their peers in Primary School (DeRosier, et, all, 1994). It means that the form of peer relationships in Primary School becomes the basis for the success pattern of peer relations in the future.

The lack of acceptance on children with special needs by their peers make them to become more powerless with the social environment and it will cause some unpleasant psychological effects. Hurlock (1998) explains there are some psychological effect that comes, namely: a) feeling loneliness because social needs are not fulfilled, b) feeling unhappy and unsafe, c) developing the unpleasant concept of self, d) lacking the necessary learning experience that is needed in order to go through the process of socialization, e) feeling very sad for not getting the happiness of their peers, f) often trying to force themselves into the group and it will increase the group's rejection to them and further minimize their chances of learning social skills, g) living in uncertainty about social reactions to them, and it will cause them to feel anxious, fearful and very sensitive, h) often doing excessive selfadaptation, hoping that it will increase social acceptance. The accumulation on some of those psychological effects will affect their learning process.

The importance of special education for regular teachers continues to grow. Teachers are expected to integrate various programs into the lives of children in order to match the special needs of children in regular education classes. In the research of Avramidis \& Norwich (2002), public education teachers show the significant increase toward their belief in inclusion. Teachers are the dominant figure in helping the children's cognitive and social development. The figure of teachers in inclusive schools, who serve all children without differentiation, is the critical determinant of children's success in peer relationships. The figures of teachers in the class are required to have the attitude of professional competence teacher as well as the competence attitude and good character. Therefore, the teachers of children with special needs are required to have the reliable competence. These competencies are technical competence and collaborative competence (Zulfija, et al, 2013; Yusuf, 1999). Westwood explains technical competence that includes: the competence of teachers in understanding various theories about children with special needs, understanding various tests related to special education, skilled in performing assessment and evaluation, skilled in teaching speaking, writing, reading, math, behavioral management and skilled in giving pre-vocational and vocational lessons. While the competence of collaborative consultation is the ability to cooperate with various related parties.

\section{CONCLUSION}

The success of inclusive education implementation for children with special needs is determined by many factors, such as teacher attitudes and peer's acceptance. The results of this research imply that positive attitudes from the teachers and good peer acceptance level are needed through systematic programming in inclusive schools. In order for the teachers to have positive attitude towards the inclusion of children with special needs to inclusive schools, training activities or workshops are required in the field of special education so that the regular teachers have comprehensive understanding of children with special needs and their learning needs. In addition, peer support is also necessary with the inclusion of children with special needs to inclusive schools. Good peer acceptance level will influence social perception and cognition both for children with special needs and for regular children. 


\section{ACKNOWLEDGMENT}

This article is based on research conducted on the teachers and children with special needs at inclusive schools in Padang, West Sumatera, Indonesia. I am grateful for a number of friends and colleagues in encouraging me to start the work, persevere with it, and finally to publish it.

1. Funding Agencies: Directorate of Research and Community Service, Directorate General of Research and Development Reinforcement, Ministry of Research, Technology and Higher Education, Appropriate Letter of Appointment Agreement of Implementation of Research Program

Number: 150 / SP2H / LT / DRPM / III / 2016 March 2016.

2. Chairman of the Institute for Research and Community Service, State University of Padang that has facilitated the implementation of this research.

\section{References}

[1] Avramidis, E., \& Norwich, B. (2002). Teachers' attitudes towards integration/ inclusion: a review of the literature. European Journal of Special Needs Education, 17(2), 129-147. doi: 10.1080/ 08856250210129056

[2] Bakker, J. T. A., \& Bosman, T. M. (2003). Selfimage and peer acceptance of Dutch students in regular and special education. Learning Disability Quarterly, 26(1), 5-14.

[3] Buhs, E. S., Ladd, G. W., \& Herald, S. L. (2006). Peer exclusion and victimization: processes that mediate the relation between peer group rejection and children's classroom engagement and achievement? Journal of Educational Psychology, 98 (1), 1-13. https://www.researchgate.net/publication/232571 291_Peer_Exclusion_and_Victimization_Proces ses_That_Mediate_the_Relation_Between_Peer Group_Rejection_and_Children $\% 27$ s_Classroo m_Engagement_and_ĀAchievement - (accessed May 30, 2017).

[4] Bear, G.G., Yang, C., Glutting, J., Huang, X., He, X., Zhang, W., \& Chen, D. (2015). Teacherstudent relationships, student-student relationships, and conduct problems in China and the U.S. Journal of International School and Educational Psychology, 2 (4), 247-260. doi: 10.1080/21683603.2014.883342.

[5] Boer, A., Pijl, S.J., Post, W., \& Minnaert, A. (2013). Peer Acceptance and Friendships of Students with Disabilities in General Education: The Role of Child, Peer, and Classroom Variables. Social Development, 22 (4), 831-844 doi: $10.1111 / \mathrm{j} .1467-9507.2012 .00670 . x$
[6] Boer, De A., Pijl, J.S., \& Minnaert, A. (2011). Regular primary school teacherse attitudes towards inclusive education: a review of the literature. International Journal of Inclusive Education, 15(3), 331-353.

[7] Bond, R. \& Castagnera, E. 2008. Peer Supports and Inclusive Education: An Underutilized Resource. Theory into Practice, 45 (3): 224-229.

[8] Bryant, D. P., Smith, D. D., \& Bryant, B. R. (2008). Teaching students with special needs in inclusive classrooms. Boston, MA: Pearson Education, Inc.

[9] Cassady, J. M. (2011). Teachers' attitudes toward the inclusion of students with autism and emotional behavioral disorder. Electronic Journal for Inclusive Education, 2 (7), 1-23.

[10]Dapudong, R. C. (2014). Teachers' knowledge and attitude towards inclusive education: basis for an enhanced professional development program. International Journal of Learning \& Development, 4 (4), 1-24.

[11]DeRosier, M. E., Kupersmidt, J.B., Patterson, C.J. (1994). Children's academic and behavioral adjustment as a function of the chronicity and proximity of peer rejection. Child Development, 65 (6), 1799-1813.

[12] Dupoux, E., Hammond, H., \& Ingalls, L. (2006). Teachers' attitudes toward students with disabilities in Haïti. International Journal of Special Education, 21 (3), 1-14.

[13] Hurlock, E. B. 1998. Perkembangan Anak Jilid 1. Jakarta: Erlangga.

[14]Lopes, J. A., Monteiro, I., \& Sil, V. (2004). Teachers' perceptions about teaching problem students in regular classrooms. Education and Treatment of Children, 27 (4), 394-419.

[15] Marlina, M. (2015). Peer mediated intervention for improving social skills of children with learning disabilities in inclusive elementary school. Jurnal Pendidikan Humaniora (JPH), 2(4), 368-382.

[16] Monaham, R., Miller, R. \& Cronic, D. (1997). Rural teachers' administrators' and counsellors', attitude towards inclusion. (ERIC Document Reproduction Service NO. ED 406 099).

[17] Ogbue, R. M. (1995). Report of the Survey of Special Education Facilities in Nigeria. Lagos Federal Government Press.

[18] Parker, J. G., \& Asher, S. R. (1993). Friendship and friendship quality in middle childhood: Links with peer group acceptance and feelings of loneliness and social dissatisfaction. Developmental Psychology, 29, 611-621.

[19]Peer Acceptance and Friendships of Students with Disabilities in General Education: The Role of Child, Peer, and Classroom Variables. Available from: https://www. researchgate.net/publication/257929469_Peer_A cceptance_and_Friendships_of_Students_with_ 
Disabilities_in_General_Education_The_Role_o f_Child_Peer_and_Classroom_Variables [accessed May 25, 2017].

[20] Peraturan Menteri Pendidikan Nasional Nomor 70 Tahun 2009 tentang Pendidikan Inklusif bagi Peserta Didik yang Memiliki Kelainan dan Potensi Kecerdasan/ Bakat Istimewa. (Online), (http://direktoratplb.com/ pendidikan), diakses 2 Mei 2017.

[21] Rizzo, T. L., \& Vispoel, W. P. (1991). Physical educators' attributes and attitudes toward teaching students with handicaps. Adapted Physical Activity Quarterly, 8(1), 4-11.

[22] Ruijs, N., Peetsma, T., \& van der Veen, I. (2010). The presence of several students with special educational needs in inclusive education and the functioning of students with special educational needs. Educational Review, 62, 137.
[23] Salend, S. J. (2001) Creating Inclusive Classrooms: Effective and Reflective Practices for All Students. Fifth Edition., New Jersey: Pearson Education, Inc.

[24] United Nations Educational Scientific Cultural Organization. (2013). Inclusive education: Addressing exclusion. Retrieved on October 13, 2013, from http: //www.unesco.org/new/en/education/themes/stre ngthening-education-systems/inclusiveeducation/browse/4/.

[25] Wentzel, K.R. (1998). Social relationships and motivation in middle school: The role of parents, teachers, and peers. Journal of Educational Psychology, 90 (2), 202-209.

[26]Zulfija, M., Indira, O., \& Elmira, U. 2013. The professional competence of teachers in inclusive education. Procedia - Social and Behavioral Sciences, 89, (10 October), 549-554. 